\title{
$\mathrm{PFA}$ 라이닝 플러그 밸브 설계를 위한 밸브 본체의 응력 \\ 시뮬레이션
}

강신한 ${ }^{*}$

${ }^{1}$ 한라대학교 기계자동차공학부

\section{A Study on the Stress Simulation for the Body Design of a PFA-lined Plug Valve}

\author{
Shin-Han Kang $^{1 *}$ \\ ${ }^{1}$ School of Mechanical \& Automotive Engineering, Halla University
}

요 약 본 논문은 주요 부위에 대한 정적응력 시뮬레이션을 퉁해 PFA 라이닝 플러그밸브 본체의 설계자를 지원하는 것을 주된 목표로 한다. $\mathrm{CAD}$ 작업을 통해 생성된 형상 모델을 스텝(step)파일로 변환하여 해석작업에 사용한다. 전문적인 해석경험이 없는 밸브 생산업체의 설계자가 형상 모델에 대한 인장, 굽힘, 비틀림 모멘트 등을 계산하는 과정을 이해함으 로써 구조적 취약점을 사전에 파악하고, 제품에 반영하여 제품 신뢰도 및 설계효율 중대에 기여할 수 있는 기본적인 방안 을 제시하고자 하였다.

\begin{abstract}
This study, is aimed to support the valve design engineer by a CAE simulation on the body of a PFA-lined plug valve, and focuses on static stress analysis, location of the weak point on bending and stiffness of the valve body. To determine whether the valve body can resist being transformed by loads, I simulated the stress distribution using CAD/CAE softwares. The 'step' file converted by CAD software after solid modeling is imported to the CAE software. Through simulation procedure, it is shown that the designed-solid-model for a valve body has stiffness on bending and torsion but has weakness for side bending moment. Also, it is expected that the valve design engineer will understand the basic process of CAE and will be able to apply on his task.
\end{abstract}

Key Words : Stress simulation, PFA-lined plug valve, Finite element, Static analysis, Solid modeling

\section{1. 서론}

통로개폐를 통하여 유체의 제어(유량, 압력, 유속), 유 체 방향전환, 수송 및 차단 등에 활용되는 밸브 중 손잡 이 휠 또는 레버로 작업자가 직접 작동시키는 밸브를 수 동밸브라 한다. 수동밸브 중 플러그 뺄브, 볼 밸브, 버터 플라이 밸브 등과 같이 $1 / 4$ 회전운동을 활용하여 유로의 변화 없이 몸체와 폐쇄요소가 직선유로를 형성하는 밸브 를 회전 밸브라 하며 가격이 저렴하고 용도가 다양하여 산업현장에서 많이 사용된다. 반도체 제조공정이나 화공 플랜트에서와 같은 화학약품 취급 요소에는 부식성 때문 에 금속제 유로를 사용할 수 없어 라이닝 밸브를 사용해 야 하며, 라이닝 플러그 뺄브(lined plug valve)는 외형상
으로는 일반적인 풀러그 밸브와 큰 차이가 없으나 [그림 1]과 같이 유로부 면과 플러그에 PFA, PTFE와 같은 불소 계 수지가 가공되어 있다[1].

라이닝 플러그 밸브에 있어 밸브 몸체와 플러그 사이 의 틈을 줄여서 유체 누설을 억제하기 위하여 밸브 중앙 부 플러그와 밸브 몸체 내면이 억지끼워맞춥 방식으로 조립된다. 라이닝을 위해 사출된 수지부는 고온에서 용융 된 상태로 밸브 본체로 주입되어 냉각되는데 이 과정에 서 수축되어 플러그를 압박하고 누설의 원인이 될 수 있 으며, 개폐동작 시 토크를 요하게 된다. 따라서 라이닝 플 러그 밸브 설계에 있어 누설방지와 회전 토크 최소화가 중요한 설계요소가 되고 있다. 최근 라이닝 수지부가 냉 각 중 발생할 수 있는 변형을 억제하는 방안 중 한 가지

*교신저자: 강신한(shkang@halla.ac.kr) 
로 수지를 본체 내면 홈에 사출한 후 냉각시켜 앵커 역할 을 함으로써 변형을 억제하는 형상설계에 관한 연구가 시도되었다[2,3]. 변형억제를 위해 가공된 홈에는 응력이 집중될 수 있으므로 수지부 형상과 더불어 본체에 대한 역학적 안정성에 관한 시뮬레이션이 필요하다.

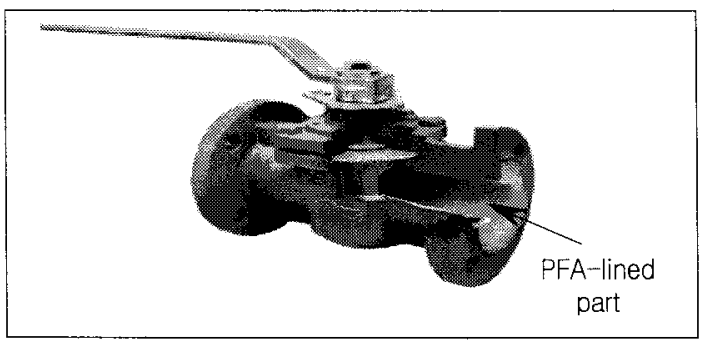

[그림 1] PFA 라이닝 플러그 밸브 예

일반적으로 제품개발은 (1)개발기획, (2)설계, (3)디자인 리뷰, (4)시작품 제작, (5)실험, (6)양산 시작품 제작, (7)양 산, (8)판매와 같은 순서로 진행된다. 실제 개발단계는 (2) (5)이고 경우에 따라서는 반복하기도 한다. 초반부일 수록 설계변경의 여지가 많고 설계 및 제품개발 비용을 줄일 수 있다. 전체 설계의 큰 틀은 초기 (2)에서 결정되 므로 (5)실험에서 문제점이 발견되더라도 개선할 수 있는 범위는 제한적이다. 개선안의 확인을 위해 시작품 제작과 실험을 수행한다면 오랜 시간과 많은 비용이 요구되며, 한 번에 품질과 비용을 만족시키지 못하면 몇 번이고 반 복해야 한다. $\mathrm{CAE}$ 를 활용하면 기계적 특성을 시작품제 작 전에 시뮬레이션으로 파악할 수 있어 효율 및 비용을 줄일 수 있는 것으로 알려지고 있다. 최근에는 CAE S/W 와 $\mathrm{H} / \mathrm{W}$ 의 발전으로 $\mathrm{CAE}$ 모델 작성이나 해석작업 자체 는 비교적 짧은 시간에 처리할 수 있게 되어 $\mathrm{CAD}$ 모델 만 있으면 간단한 문제인 경우 수분 내에 해석결과를 얻 을 수 있게 되었으므로 초기설계 과정에서 설계자가 이 를 담당함과 동시에 $\mathrm{CAD}$ 와 $\mathrm{CAE}$ 를 연계하여 적극 활용 하는 방안을 고려하여야 할 것이다[4,5].

국내 라이닝 플러그 밸브 제조사는 대부분 중소기업으 로, 치열한 경쟁 속에 놓여 있다. 품질은 높이고 단가는 낮춰야 하는 환경에서 설계과정 중 해석에 대한 관심이 높아지고 있으나 경험과 예산 부족에 따른 부담감이 큰 것이 현실이다. 본 논문에서는 밸브 생산업체와 기술개발 및 기술지도 등을 통해 기업에 지원되었던 산학협력 내 용을 소개하고자 한다. 설계담당자의 입장에서 자신이 생 성한 $\mathrm{CAD}$ 모델을 활용하여 응력해석을 수행하는 과정을 이해하여 제품설계 효율향상에 기여할 수 있는 방안을 제 시하고 이를 신제품 개발에 활용할 수 있도록 지원하였다.

\section{2. 연구 목표 및 방법}

\section{1 연구 목표}

라이닝 플러그 밸브의 핵심은 내부에 사출되는 불소계 수지의 변형을 최소화하여 누설과 조작력을 최소화하는 데 있다. 본 연구에서는 PFA 라이닝 폴러그 밸브 본체에 대한 설계를 지원하기 위해 수행되었던 3 인치 밸브의 수 지부 형상설계에 이어, 이를 제품화했을 때 발생할 수 있 는 응력분포에 대한 시뮬레이션 과정을 주된 내용으로 하고 있다. 해석작업은 초기설계 후 해석기술자에 의해 별도로 수행해 왔으나, 최근 '설계를 위한 해석(analysis for design)'에 관한 관심과 활용이 증대됨에 따라 설계과 정에서 시뮬레이션을 통해 신뢰도와 효율을 높이는 방향 으로 전개되고 있다. 기존 연구를 통해 얻어진 수지부 형 상을 적용한 본체 하우징에 대한 응력 시뮬레이션을 활 용하여 제품이 현장에 장착되었을 때 구조적으로 안전하 게 사용할 수 있는가에 대한 검토를 하고자 하였다. 전체 적인 진행과정은 [그림 2]와 같으며, 변형이 고려된 PFA 수지부 형상설계와 관련된 전반 2 개 과정은 완료되었고, 본 논문은 그 후과정에 의해 수행된 내용을 언급하고 있 다. 모델링에는 기업에서 설계에 사용하는 'SolidWorks' 를, 해석작업에는 대학이 보유한 'Nastran for Windows' 를 활용하였다 $[6,7,8]$.

\section{2 유한요소 모델링}

$\mathrm{CAD}$ 작업을 통해 본체 하우징 모델을 얻게 되면 내부 서피스를 추출하여 수지부를 모델링한다. 수지부 외면에 는 변형을 억제하기 위한 형상이 추가되어 있어 이를 본 체의 내부면에 반영해야 한다. 하우징 형상과 수지부 형 상 사이에 불 연산(Boolean operation)을 적용하여 겹치는 부분을 제거(subtraction)하는 방식으로 하우징을 수정하 면 작업이 수월해 진다.

SolidWorks인 경우, 작업메뉴에서 Combine을 클릭하 고 옵션으로 'subtract' 설정 후, 기준이 되는 'main body' 와 제거되어야 할 대상인 'Bodys to Combine'을 지정하면 수행할 수 있다. CAD 작업을 통해 얻어진 모델은 'step' 파일로 변환되어 해석 소프트웨어로 입력되며 Intel P4-3.2GHz CPU, 2GB RAM, Radeon 9600 VGA, XP-pro 가 장착된 $\mathrm{PC}$ 를 사용하였다. 최근에는 COSMOSWorks, $\mathrm{ALGOR}$ 등과 같은 해석 소프트웨어가 SolidWorks에 결 합되어 제공되고 있다. 이 경우에는 $\mathrm{CAD}$ 화면상에서 해 석작업을 바로 수행할 수 있어, 각 소프트웨어를 따로 구 동하거나 파일을 변환할 필요가 없어 시간이 단축되는 장점을 갖는다. 모델이 입력되면 해석을 위해 요소 
(element)로 분할해야 한다. 대부분의 해석 소프트웨어에 서는 솔리드 형상에 대해 자동으로 요소 분할하는 기능 을 갖고 있어 활용이 가능하다. 전문적인 해석을 위해서 는 각 부위별로 적절하게 크기를 다르게 지정하여 분할 함으로써 계산의 정확도를 높이는 것이 좋다.

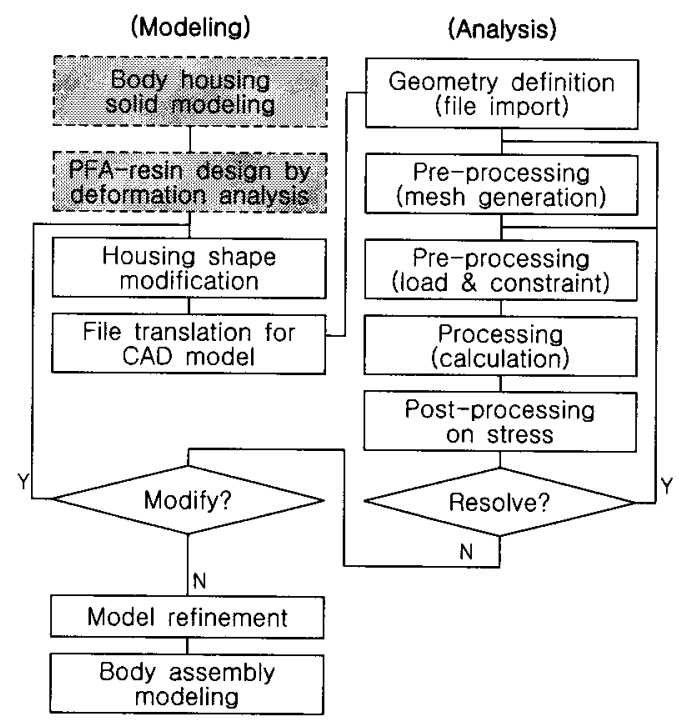

[그림 2] 밸브 본체 설계과정

요소는 해석 소프트웨어 'Nastran for Windows'에서 제 공하는 솔리드 요소를 사용하였으며, 자동 분할기능을 통 해 [그림 3]과 같이 해석모델을 생성하였다. 일반적으로 소프트웨어에서 제공하는 자동 메쉬 기능을 사용하면 솔 리드 사면체 요소가 주종을 이룬다. 자동메쉬 생성 소프 트웨어가 보급되기 전에는 솔리드 요소로 육면체 요소가 많이 사용되었으며 실제로 육면체 요소가 정확도가 높은 계산결과를 얻을 수 있다. 그러나 육면체 요소는 곡면에 대한 대응이 어려워 자동으로 메쉬를 생성하는 경우에는 곡면부 표현이 용이한 사면체 요소가 주로 사용된다. 사 면체 요소에는 [그림 4]와 같이 4개 절점(node)을 갖는 1 차 요소, 10 개 절점으로 구성되는 2차 요소가 있으며, 절 점이 많은 2 차 요소가 1 차 요소에 비해 변형을 보다 잘 표현하고 정확도가 높은 결과를 얻을 수 있다[9]. 요소 종 류와 함께 요소의 크기가 계산의 정확도를 좌우하는 중 요한 요인이 되는데, 본 연구에서는 요소분할 기본 크기 로 $4[\mathrm{~mm}]$ 자동분할, 10 노드 2 차 사면체 요소를 사용하였 다. 요소분할과 함께 정의되는 재료의 물성값은 [표 1]과 같으며, $\mathrm{CAD}$ 소프트웨어에서 제공하는 라이브러리 (library)를 활용하였다. SolidWorks 모델링 환경 트리부
상단의 재료선정 단계에서 라이브러리에서 강(steel)의 범 주에 속해 있는 'Cast carbon streel'을 선택하였으며, 이 는 하우징 본체가 주조공정을 통해 제작되는 것을 고려 한 것이다.

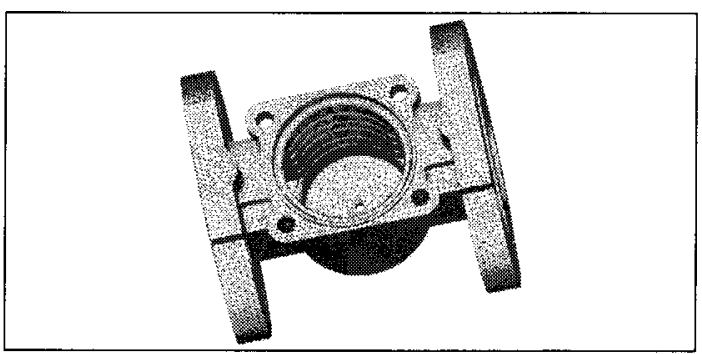

[그림 3] 밸브 본체 유한요소 모델

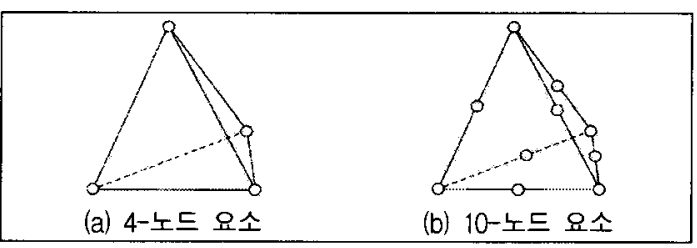

[그림 4] 사면체 솔리드 요소

[표 1] 밸브 본체 하우징 물성값

\begin{tabular}{|c|c|c|c|}
\hline 2? & 항 목 & 물성값 & crid \\
\hline \multirow{4}{*}{$\begin{array}{c}\text { 기계적 } \\
\text { 성질 }\end{array}$} & Young's Modulus & 200,000 & $\mathrm{MPa}$ \\
\hline & Poisson's ratio & 0.32 & - \\
\hline & Yield stress & 248 & $\mathrm{MPa}$ \\
\hline & Density & 0.0078 & $\mathrm{~g} / \mathrm{mm}^{3}$ \\
\hline \multirow{2}{*}{ 운전조건 } & Pressure & 10 & $\mathrm{~kg}_{f} / \mathrm{cm}^{2}$ \\
\hline & On/off torque & 15 & $\mathrm{~kg}_{\mathrm{f}}-\mathrm{m}$ \\
\hline
\end{tabular}

\section{3. 시뮬레이션}

\section{1 밸브 동작 압력에 따른 응력}

운전압력이 본체 내부에 미치는 영향을 살펴보기 위해 압력하중에 의한 응력분포를 구하였다. 응력계산에 있어 서는 요소의 크기가 결과에 미치는 영향이 큰 것으로 알 려져 있으며, 크기가 작을수록 코너부 형상을 세세하게 표현할 수 있어 계산이 정확해 질 수 있으나, 너무 작게 나누면 계산소요 시간이 매우 길어지기 때문에 적절한 수준에서 그 크기를 결정해야 한다. [그림 5]는 한 예를 보여주는데, (a)에서와 같이 밸브 본체 내면을 작용면으 로 하고 압력을 하중조건으로, 양 끝단 플랜지부에 있는 볼트 구멍 8 개를 고정하는 것을 구속조건으로 부여하였 다. 밸브 사용압력인 $10\left[\mathrm{~kg}_{f} / \mathrm{cm}^{2}\right]$ 의 10 배인 $100\left[\mathrm{~kg}_{f} / \mathrm{cm}^{2}\right]$ 
를 적용하여 이에 해당하는 $9.8[\mathrm{MPa}]$ 를 압력하중으로 정 의하였다. (b)는 계산결과를 보여주는데, 기본 메쉬 크기 를 4[mm], 결과 표현에 사용하는 Display scale factor를 $3 \%$ 로 했을 때의 모습이다. 이로부터 응력값이 크게 작용 하는 몇 군데 위치 중 3 개 지점을 선정하여 다음 과정에 이어지는 사례별 비교 대상으로 설정하였다. (c)와 (d)는 기본 크기가 각각 $4[\mathrm{~mm}]$ 와 $7[\mathrm{~mm}]$ 인 경우에 대한 응력값 을 길이방향에 대해 표현한 것으로, 요소 크기가 큰 경우 가 작은 경우보다 응력값이 작게 계산되었고, 모서리와 코너부에 집중되는 국부적으로 커지는 응력을 제대로 표 현하지 못함을 알 수 있다. (b)에 표시된 관심지점은 요소 크기별 계산결과를 비교하기 위해 사용될 것이며 다음과 같은 위치를 의미한다.

(1) 내부 유로 플랜지 접촉부 하단 모서리

(2) 내부 유로 플랜지 접촉부 상단 모서리

(3) 본체 외부 플랜지 모서리

그림에 표현된 응력은 von-Mises 응력으로, 단위는 $[\mathrm{MPa}]$ 로 $\left[\mathrm{N} / \mathrm{mm}^{2}\right]$ 에 해당하며, 이후에 표현된 모든 결과 에서 사용한다. 요소의 크기가 계산 결과에 미치는 영향 을 살펴보기 위해 $10,7,5,4,3[\mathrm{~mm}]$ 로 분할한 후 결과롤 비교한 것이 [표 2]로 크기별 노드수, 요소수, 계산시간, 응력 관심위치 3 곳에서의 결과를 보여준다. 기본 크기가 작아질수록 노드수와 요소수, 계산시간이 급격하게 증가 함을 알 수 있다. [표 2]에서 응력값은 관심지점에 주위에 분포되어 있는 요소 응력값 중 최대값을 나타낸 것이다.

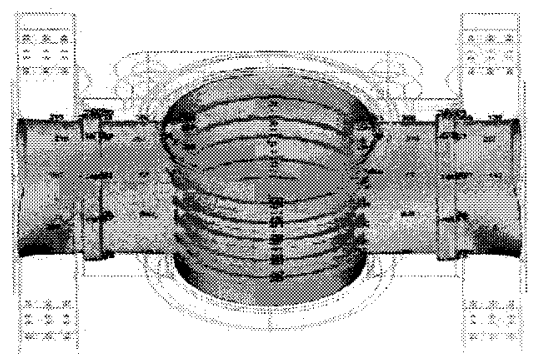

(a) 하중 및 경계조건

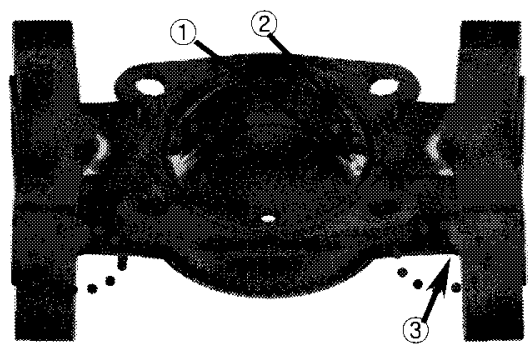

(b) 응력분포 및 관심지점

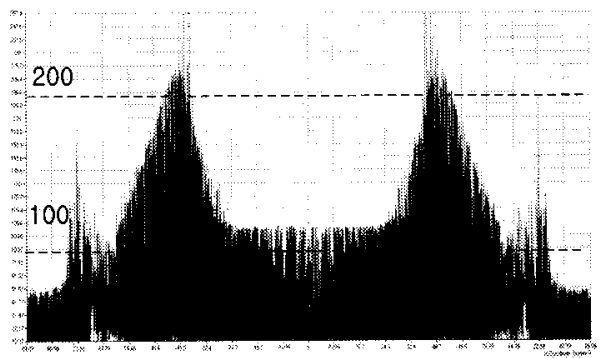

(c) von-Mises 응력(기본크기: 4[mm], [MPa])

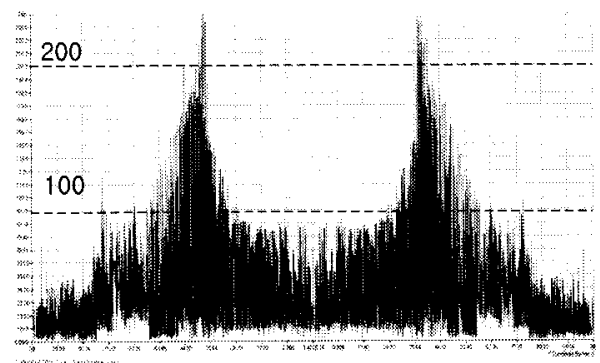

(c) von-Mises 응력(기본크기: 7[mm], [MPa])

[그림 5] 내압하중에 따른 응력 시물레이션

[표 2] 요소 크기별 톡성

\begin{tabular}{|c|c|c|c|}
\hline \multirow{2}{*}{$\begin{array}{c}\text { Mesh size } \\
\text { [mm] }\end{array}$} & Total nodes & Toval elements & Caleviafior tíme [s] \\
\hline & Stress al 1 & Stressol2 & Sirensos $(\mathrm{MPa}$ \\
\hline \multirow{2}{*}{10} & 29,797 & 15,104 & 26 \\
\hline & 190 & 243 & 78 \\
\hline \multirow{2}{*}{7} & 53,672 & 28,393 & 70 \\
\hline & 244 & 219 & 90 \\
\hline \multirow{2}{*}{5} & 102,385 & 56,703 & 246 \\
\hline & 260 & 232 & 104 \\
\hline \multirow{2}{*}{4} & 185,608 & 107,775 & 792 \\
\hline & 263 & 256 & 125 \\
\hline \multirow{2}{*}{3} & 362,892 & 220,382 & 3,064 \\
\hline & 277 & 263 & 130 \\
\hline
\end{tabular}

본 연구에서는 정확한 계산 결과보다는 초기설계과정 에서 설계자가 응력해석의 흐름을 이해하고 반영하여 효 율적인 초기설계가 가능하도록 지원함에 목표를 두고 있 어 결과와 시간이 양호하다고 판단되는 $4 \mathrm{~mm}$ 를 기본 크기 로 설정하고 이후 모든 시뮬레이션 과정에서 적용하였다.

\section{2 길이방향 인장 및 굽힘하중에 따른 응력}

인장 및 굽함에 따른 응력 발생을 살펴보기 위해 [그림 6]과 [표 3]과 같이 하중조건과 경계조건을 설정하였다. 밸브가 파이프와 플랜지로 체결되는 점을 고려하여 경계 조건으로 한 쪽 플랜지부 구멍 4곳을 고정시킨 후 하중조 건으로 반대쪽 플랜지부 구멍 4곳에 길이방향 인장하중, 옆쪽, 위쪽, 아래쪽 방향으로 굽힘하중을 가하는 조건을 
설정하였다. 각 하중에 대한 응력과 변형량 계산에는 정 적해석(static analysis)모듈을 사용하였다. 결과 표현을 위 해 [그림 6]에서와 같이 응력이 집중될 것으로 예상되는 지점을 선택하여 결과를 정리한 것이 [그림 7]이다. 인장 하중인 경우 하중이 가해지는 플랜지 쪽 코너와 모서리부 에 응력이 집중되었으며, 변위도 가장 크게 발생하였다. 굽힘하중인 경우에는 고정 플랜지 쪽에 위치한 모서리 부에서 응력이 크게 계산되었으며, 위 또는 아래쪽 하중 보다는 좌우측 방향 굽힘하중에서 응력이 크게 발생할 것으로 예측되었다. 측면 굽힘인 경우 최대응력이 항복응 력보다 큰 것으로 나타났다. 위치는 위쪽 뚜쩡(cap)부 아 래쪽 평면이 플러그부와 유로부와 이루는 곡면과 교차하 는 곳에 나타나는 곳이다. [그림 7]에 나타난 5 개 지점은 인장인 경우이고, 굽힙의 경우에는 고정되는 플랜지 부위 쪽에 대칭되는 지점에서의 응력값을 그림에 나타냈다.

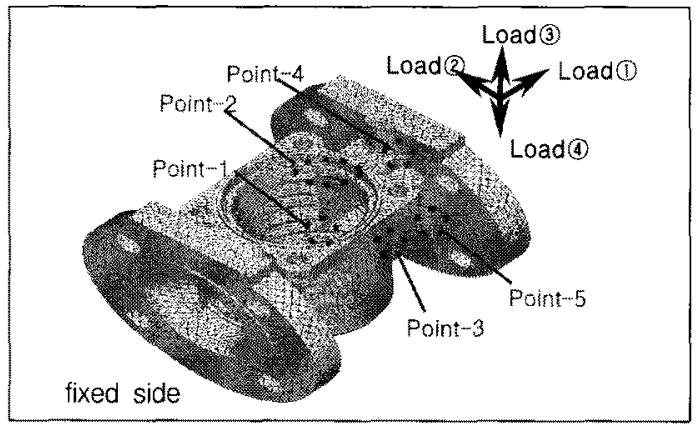

[그림 6] 인장/굽힘 시뮬레이션 조건

[표 3] 인장/귭힘 하중

\begin{tabular}{|c|c|c|c|}
\hline \multicolumn{2}{|c|}{ Tern } & Vine lavi & Renark \\
\hline Tensile & Load 1 & 60 (15/hole) & - axial force \\
\hline \multirow{3}{*}{ Bending } & Load 2 & 20 (5/hole) & - force to side direc \\
\hline & Load 3 & 20 (5/hole) & - upward force \\
\hline & Load 4 & 20 (5/hole $)$ & - downward forc \\
\hline
\end{tabular}

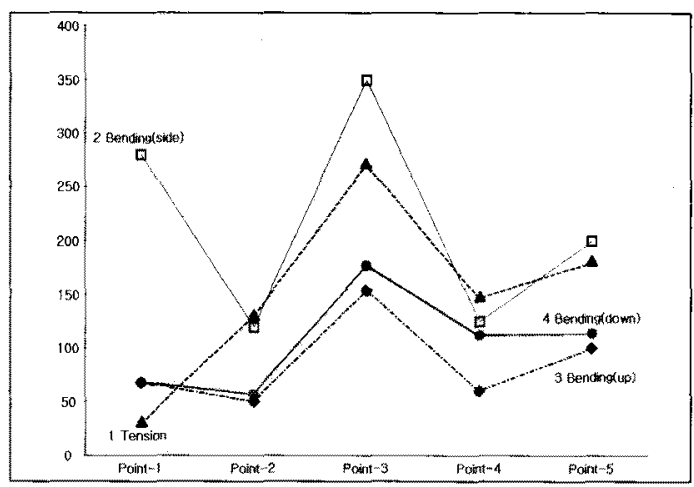

[그림 7] 인장/굽힘 시뮬레이션 결과

\section{4. 검 토}

시뮬레이션 결과 전반적인 응력분포가 양호한 것으로 보이지만, 고체역학적 관점에서 고려해야 할 응력집중 현 상이 코너부에 예외 없이 발생함을 볼 수 있다. 응력집중 을 억제하기 위한 방법 중 하나가 라운딩으로, 먼저 플러 그 위쪽 뚜껑 결합부 형상을 90 도 회전시킨 후, 본체 외 부 플랜지부와 플러그부가 유로부와 연결되는 모서리와 코너를 라운딩 처리를 하였다.

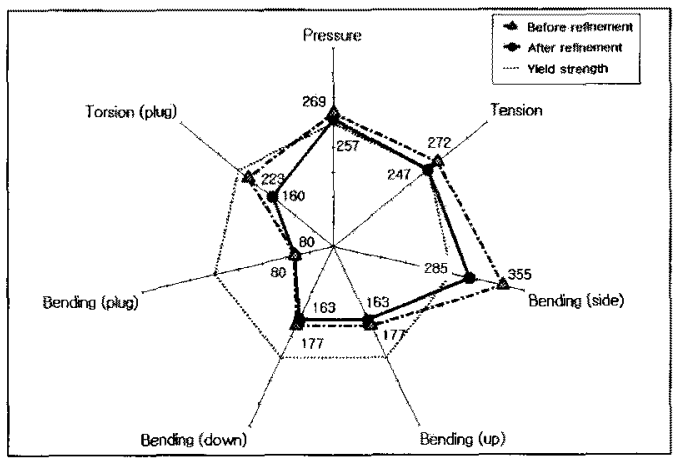

[그림 8] 마무리된 본체에 대한 응력계산 결과

다듬어진 모델에 대해 시뮬레이션을 다시 한 결과 모 서리와 코너에 발생하는 응력이 감소되었음을 알 수 있 었다. 수정모델에 대한 응력 시뮬레이션 결과를 [그림 8] 에 정리하였는데, 각 사례별 최대응력을 보여주고 있으며 단위는 [MPa]이다. 그림에서 일점쇄선은 수정 전 최초모 델에 대한 것이고, 실선은 다듬기작업이 수행된 모델에 대한 계산 결과이며, 흐린 점선은 항복응력(yield strength)을 의미한다. 플러그 부위에서 굽힘과 비틀림에 대한 시뮬레이션도 수행되었는데, 응력이 크지 않아 다른 경우에 비해 영향이 적다고 할 수 있다. 본 논문에서는 웅력을 von-Mises 응력으로 표현하였으며, 이는 구조물 에 작용하는 3 차원적 응력을 이해하기 십게 스칼라 값으 로 변환한 것이라 할 수 있다. 이 값이 항복응력보다 큰 경우에는 해당 부위에서 소성변형이 일어날 수 있어 점 검이 필요하며, 집중된 응력이 부적절한 메쉬에 의한 계 산상 오류가 아닌가에 대한 여부도 함께 검토되어야 한 다[10]. 그림에서도 항복응력을 초과하는 부분이 있는데 하중을 작동환경보다 과도하게 적용하였기 때문에 나타 난 현상으로, 향후 세밀한 분석을 요하는 사항이다. 응력 시물레이션을 통해 응력이 집중될 수 있는 부위를 예상 하고 이에 대한 보완을 할 수 있는 형상 다듬기 과정을 거쳐 제안된 밸브 본체 조립모델을 [그립 9]에 나타냈다. 모든 작업이 끝나 확정된 모델은 아니며, 상하방향 하중 
은 뚜껑부와 플러그부와 함께 지지되어 구조적으로 튼튼 하지만, 좌우측방향 하중에는 플랜지부에 의해서만 지지 되므로 상대적으로 취약하여 이를 해소할 수 있는 구조 개선이 추가되어야 한다.

이상과 같이 해석분야에 대한 경험이 부족한 설계자의 입장에서 초기설계 중 발생할 수 있는 역학적 거동을 예 측하여 설계에 반영함을 목적으로, 정확한 결과값 보다는 전체적인 경향을 살펴보기 위한 기본적인 방식에 의해 진행되었다. 정적해석 모듈을 중심으로 시뮬레이션을 진 행하는 과정을 정립하기 위하여 노력하였으며 설계담당 자가 이를 소화하여 신제품 개발에 적용할 수 있는 기반 을 마련하였다. 보다 정확한 해석결과를 얻기 위해서는 몇 가지 보완이 요구되며, 비선형 해석, 모델 다양화 등은 그 예이다. 본 연구에서는 설계자가 변형되는 모습을 쉽 게 확인하고 이해할 수 있도록 하기 위해 형상 전체를 해 석모델로 사용하였으나, 요소 세분화와 계산시간 단축이 가능한 $1 / 2$ 모델을 사용하는 것도 고려해야 한다. 각 과 정에서 제시된 하중과 구속조건이 실제상황과 얼마나 유 사한가에 대한 것과 현장에 적용할 때 나타나는 유체유 동에 기인한 압력변화[11], 진동 및 파괴하중과 같은 요 인을 고려한 전문적인 해석이[12,13] 수반될 경우 보다 품질이 우수한 밸브설계가 가능하다. 이와 같은 작업은 해석전문가의 지원이 절대적으로 필요하며, 설계자가 단 시간 내에 획득할 수 있는 기술은 아니므로 밸브 및 배관 용 부품과 관련된 자료를 정리하고 정보를 제공할 수 있 는 네트워크를 형성해야 한다. 설계는 회사에서 해석은 대학에서 지원하는 실질적인 산학협력체제 구축이 필요 하다 할 것이다.

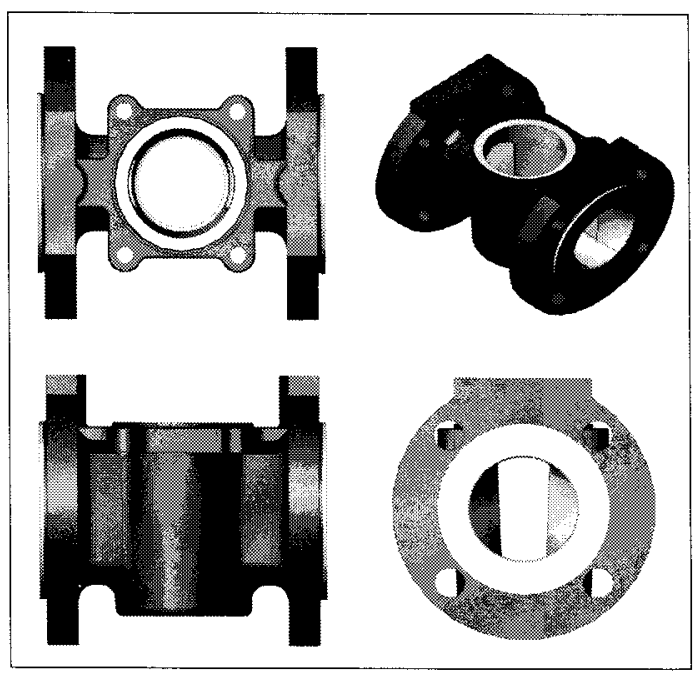

[그림 9] 밸브 본체의 조립 모델

\section{5. 결 론}

본 연구를 통해 라이닝 쯜러그 밸브 해석경험이 없는 설계자가 초기설계 과정에서 나타날 수 있는 구조적 오 류를 발견하여 사전에 변경할 수 있는 방안을 제시하고 자 하였다. 결과를 요약하면 다음과 같다.

1) 밸브 모델링부터 해석까지 전 과정을 참여기업과 함께 하여, 기업의 설계담당자가 전체 과정을 이해하였다. 이를 통해 초기설계 단계에서 역학적 취약점을 발견하 고 설계에 반영할 수 있어 설계 신뢰도와 효율이 증대 될 수 있을 것으로 기대된다.

2) 시뮬레이션 결과 본체 내부에 수지부 변형을 억제할 목적으로 가공된 홈 주위에서 보다는 유로부와 플랜 지부 모서리와 코너에 더 큰 응력이 발생하며, 본체 외부에 모서리나 코너부에 크게 집중되는 응력은 본 체 외부 코너부에 대한 라운덩을 통해 상당부분 감소 시킬 수 있는 것으로 나타났다.

3) 정적상태에서 밸브 좌우측 방향으로 하중에 의해 발생하 는 굽힘응력이 상하방향으로 가해지는 하중에 의한 응력 보다 크게 나타나므로 플랜지부에 대한 형상 보완이 요 구된다. 플러그부 굽힘과 비틀림 응력은 크지 않았다.

4) 본 연구에서는 정적해석을 중심으로 시뮬레이션을 수 행하였으나, 현장에서 발생할 수 있는 유동과 진동에 의한 비선형 요인을 고려한 전문적이고 세분화된 해 석이 이어지면 더 큰 효과를 기대할 수 있다. 이를 위 해 대학과 기업의 실질적인 협력체제 구축이 필요한 것으로 사료된다.

\section{참고문헌}

[1] http://www.crp.co.uk/plugvalves.aspx?page=19

[2] 강신한, "PFA-lined 플러그 밸브의 내면수지부 형상 설계”, 한라대학교 논문집, 제 9집, pp.39-46, 2006

[3] 강신한, "CAD 소프트웨어를 활용한 3인치 PFA 라이 닝 플러그 밸브 본체의 형상설계", 산업경영시스템학 회지, Vol. 32, 2009년 3월 게재예정.

[4] 민승재, "설계자를 위한 해석입문-제1회 기본을 알면 두렵지 않다", 한국 $\mathrm{CAD} / \mathrm{CAM}$ 학회지, 제 12 권 제 1 호, pp.26-29, 2006.

[5] 秋山雅弘, "CAD와 $\mathrm{CAE}$ 의 연계에 관하여", 한국소성 가공학회지, 제17권 제5호, pp.313-321, 2008.

[6] 정인선 외 3 인 공저, SolidWorks Bible \& Training, 도서출판 과학기술, 2005.

[7] MSC/NASTRAN for Windows Quick Start Guide, The MacNeal-Schwendler Corporation, 2000. 
[8] 귄진회 외 5인 공저, NASTRAN으로 배우는 전산구 조해석, 경문사, pp.90-116, 2004.

[9] 민승재, “설계자를 위한 해석입문-제2회 정확도는 메 쉬로 결정된다", 한국 $\mathrm{CAD} / \mathrm{CAM}$ 학회지, 제 12 권 3 호, pp.28-32, 2006.

[10] 민승재, "설계자를 위한 해석입문-제7회(최종회): 해 석결과 확인", 한국 $\mathrm{CAD} / \mathrm{CAM}$ 학회지, 제14권 2호, pp.19-23, 2008.

[11] 정원락, 홍성철, “집진기의 공기소모량과 백 필터내 의 압력전파에 대한 실험적 연구”, 한국산학기술학회 논문지, Vol.9, No.4, pp.886-891, 2008.

[12] 조재웅, 한문식, "자동차 암에 있어서의 피로변형의 시뮬레이션 해석에 관한 연구”, 한국산학기술학회논 문지, Vol.8, No.3, pp.427-431, 2007.

[13] 김정순 외 3 인, "페트용기 성형을 위한 프리폼 사출 성형 및 블로우 성형의 실험 및 해석에 관한 연구”, 산학기술학회논문지, Vol.9, No.5, pp.1119-1124, 2008.

\section{강 신 한(Shin Han Kang)}

[정회원]

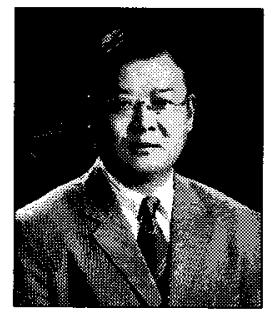

- 1986년 2월 : 인하대학교 기계공 학과 (공학사)

- 1988년 2월 : 인하대학교 대학원 기계공학과/고체 및 생산공학전 공 (공학석사)

- 1995년 2월 : 인하대학교 대학원 기계공학과/자동화공학전공(공학 박사)

- 1996년 2월 현재 : 한라대학교 기계자동차공학부 전 임강사, 조교수, 부교수

<관심분야>

자동화 소프트웨어, 지능형 시스템, 자동차 부품설계, 자 동차 전기전자 